\title{
Tongue disorders due to megaloblastic anaemia and its management: A case report.
}

\author{
Md. Ashif Iqbal ${ }^{{ }^{*}}$, Rina Niroula ${ }^{{ }^{\dagger}}$, Prima Singh ${ }^{3^{\dagger}}$, Mehnaz Khan ${ }^{4}$
}

\section{AFFILIATION:}

1. Md. Ashif Iqbal*

Associate Professor \& Head

Dept. of Periodontology \& Oral Pathology

Update Dental College, Bangladesh

Mail: drasif100@gmail.com

2. Rina Niroula ${ }^{\dagger}$

Graduated from Update Dental College, Bangladesh

Batch: UpDC-09

Address: Kathmandu, Nepal

Mail: niroularina@gmail.com,Cell: +9779860790958

3. Prima Singh ${ }^{\dagger}$

Graduated from Update Dental College, Bangladesh

Batch: UpDC-09

Address: Chagal-15, Kathmandu, Nepal

Mail: primasingh270@gmail.com , Cell: +9779843640945

4. Mehnaz Khan

Update Dental College, Batch : UpDC-9, from Lalitpur, Nepal

Email: mehnazkhan24610@gmail.com, Cell: +9779861222185

$(t)$ : These Authors contributed equally to this work

\section{Article info.}

Received: 17 January 2021

Accepted: 23 February 2021

Volume: Vol-11, Issue-1, April 2021

DOI: https://doi.org/10.3329/updcj.v11i1.53006

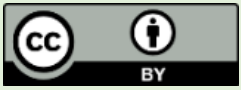

(c) Authors retain copyright and grant the journal right of first publication with the work simultaneously licensed under Creative Commons Attribution License CC - BY 4.0 that allows others to share the work with an acknowledgment of the work's authorship and initial publication in this journal.

https://creativecommons.org/licenses/by/4.0/

Publisher: Update Dental College, Dhaka, Bangladesh

Web: www.updatedentalcollege.edu.bd

E-mail: updcj@hotmail.com

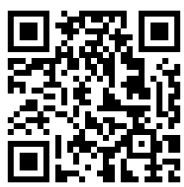

\footnotetext{
Scan QR code to see the latest issue

* Corresponding Author Md. Ashif Iqbal* Associate Professor \& Head Dept. of Periodontology \& Oral Pathology Update Dental College, Bangladesh

Mail: drasif100@gmail.com

https://orcid.org/0000-0002-9490-7927
}

Cell: +8801716116080

\section{ABSTRACT:}

The presence of megaloblasts and macrocytes in the bone marrow characterizes megaloblastic anaemia. Megaloblastic anaemia is the result of folate and vitamin B12 deficiency in more than $95 \%$ of cases. We hereby report a case of megaloblastic anaemia in a 23-year old female having glossitis and a burning sensation on the tongue. The blood picture showed megaloblastic anaemia and haematological tests confirmed the diagnosis. The patient positively responded to vitamin B12 and folic acid supplementation. The presence of oral signs and symptoms offer the dentist an opportunity to participate in the diagnosis of this condition. Early diagnosis is important to prevent deficiency. This paper explains the oral changes induced by dietary deficiency of cobalamin or folate in a patient with megaloblastic anaemia.

\section{KEYWORDS: Megaloblastic anaemia, vitamin B12 deficiency, folic acid deficiency}

\section{INTRODUCTION}

Megaloblastic anemia (MBA), also known as macrocytic anemia, is characterized by a decreased number of RBCs as well as the presence of unusually large, abnormal, and poorly developed erythrocytes(megaloblasts), and because of the greater size, they are unable to enter the bloodstream ${ }^{1}$. The most common cause is the vitamin B12 and vitamin B9 deficiency ${ }^{2}$. Vitamin B12 is absorbed in the terminal ileum. The intrinsic factor, a glycoprotein secreted by parietal cells in the stomach mucosa, is almost exclusively responsible for this absorption. Intrinsic factor binds to vitamin B12, and the complex is transported across the cell membrane-bound to another glycoprotein called transcobalamin ${ }^{3}$. So the vitamin b12 deficiency is either due to a lack of intrinsic factors and/or the lack of a sufficient amount of VB12 in the diet.

Similarly, folic acid deficiency may also be due to the lack of intake of vitamin b9 rich foods. Green leafy vegetables, legumes, certain fruits, and fortified cereals and cereal products are the most important sources of folate in the diet. In lactating mothers, if the lactating period is prolonged it may cause folate depletion in some women. Folate deficiency is caused by a variety of factors in chronic alcoholism. These include low folate intake, poor folate absorption due to impaired transcription of the intestinal folate carrier reduced liver uptake and storage ${ }^{4}$.

Pale mucous membranes, erythema, glossitis, chronic aphthous stomatitis, angular cheilitis, and oral candidiasis are the most widely recorded oral cavity signs of iron, vitamin B12, and folic acid deficiency ${ }^{5}$. The diagnosis of a nutritional or vitamin deficiency is based on patients' history, physical examination, and laboratory findings. When oral signs and symptoms are identified, iron, vitamin B12, and folic acid deficiencies are commonly considered in differential diagnoses 5 .

CASE REPORT:

A 23-year-old female reported to the Department of Periodontology and Oral Medicine with the chief complaint of a burning sensation on the tongue. The burning sensation was more while taking food. The current symptoms had been present for more than 3 days. Her previous medical and dental records were non-contributory and she did not disclose any allergy history.

During clinical evaluation fissures on the tongue was seen. Also, glossitis with papillary atrophy was detected, but no ulceration was 
Update Dental College Journal (UpDCJ): Vol- 11, Issue-1

evident. The tongue was also little puffy dorsally. The tongue was mild blackish pigmented for 3-4 months due to use of charcoal toothpaste. She also exhibited a taste disturbance. No sign of anaemia present in lower conjunctiva and no lymphadenopathy was present.
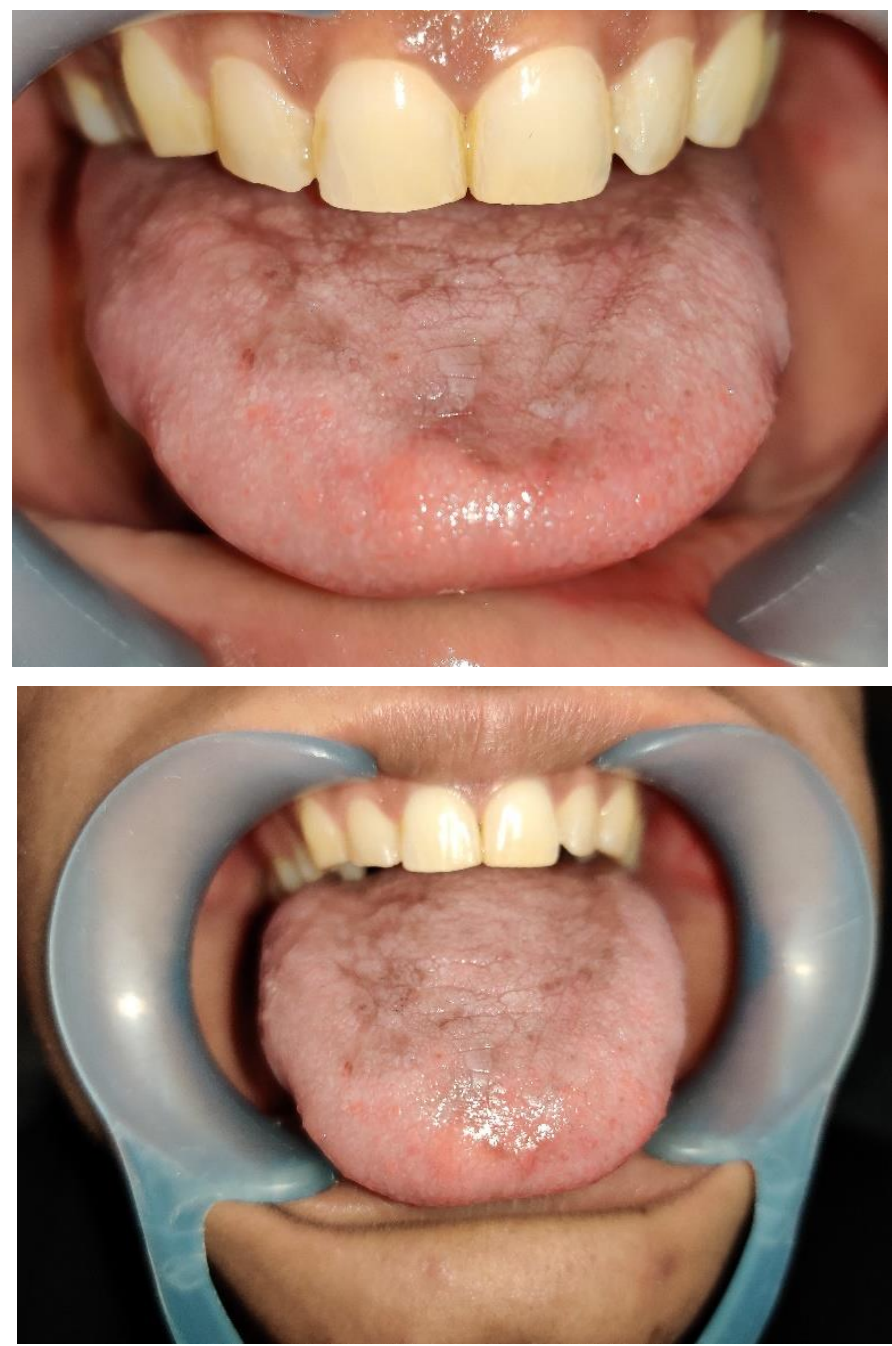

Figure: At first visit: Glossitis with papillary atrophy was detected, but no ulceration was evident. The tongue was also little puffy dorsally. The tongue was mild blackish pigmente

After taking her history and clinical examination we advised her to stop the use of charcoal toothpaste and suggested using baby toothpaste. Based on the patient's history and clinical examination, she was prescribed vitamin A, C, E supplements once daily for 15 days, as well as povidone-iodine mouthwash. She was later advised to undergo haematological tests.

The haematological test revealed an elevated mean corpuscular volume that indicated megaloblastic anaemia. After the revelation, previous therapy was stopped and the oral doses of vitamin B9, B12 supplementation was prescribed once daily for 15 days. The patient was advised to modify her diet by taking nutritious food. She was suggested to take diets rich in folic acid like spinach, lettuce, eggs, liver. For further confirmation, she was referred to the medicine department and the doctor advised her to take some tests that are serum vitamin b9, b12, PBF. After a few days, laboratory investigation revealed normal findings. She was advised to follow up on an OPD

27| P a g e
Md. Ashif lqbal et al.

basis. Following a 1-month recall visit, the patient showed progress in the following parameters: features of Glossitis and burning sensations on the tongue have significantly decreased. Pateint mention no clinical symptoms, but intraoral features not fully resolved. Some signs of atrphy of filliform papillae were still present. We have suggested patient to clean her tongue regularly after brushing and increase dieatary soirce of antioxidant to enhance epithelial proliferation more.

\section{TABLE 1}

PATIENT'S HEMATOLOGIC TEST RESULTS WITH NORMAL VALUES :-

\begin{tabular}{lll}
\hline Tests & $\begin{array}{l}\text { Normal } \\
\text { range(female) }\end{array}$ & Patient's value \\
\hline RBC & $3.8-5.8$ & 3.68 \\
\hline Haemoglobin & $10.0-14.0$ & 11.8 \\
\hline ESR & $1-20 \mathrm{~mm} / 1^{\text {st }}$ hour & $32 \mathrm{~mm} / 1^{\text {st }}$ hour \\
\hline MCV & $76.0-94.0$ & 104.6 \\
\hline MCH & $27.0-32.0$ & 32.1 \\
\hline Vitamin B12 & $239-931$ & 260.0 \\
\hline Vitamin B9 & $3.1-12.4$ & \\
\hline
\end{tabular}

$\mathrm{Mcv}=$ mean corpuscular volume, $\mathrm{RBC}=$ red blood cell, $\mathrm{ESR}=$ erythrocyte sedimentation rate, $\mathrm{Mch}=$ mean corpuscular haemoglobin

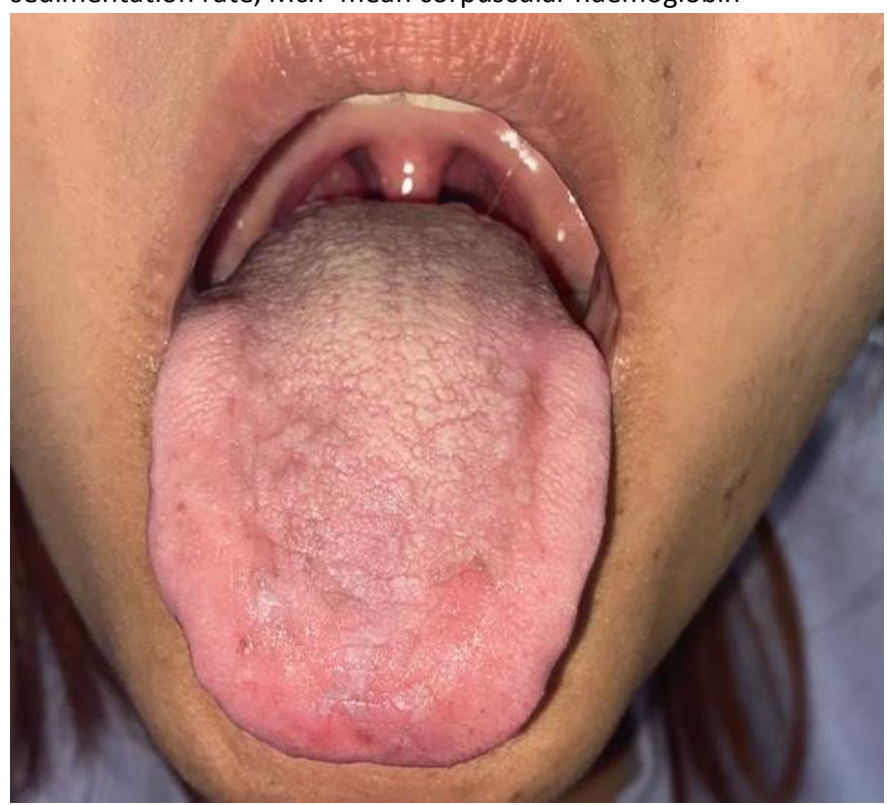

Figure: Follow up after 1 month: significantly reduced features of glossitis but not completely resolved.

\section{DISCUSSION:}

In our case, oral signs and symptoms, as well as irregular blood tests, were found to be more common. The patient had burning mouth syndrome, a glossy tongue and a slightly black tongue as well as a fourmonth history of using charcoal toothpaste which actually confused us and our seniors that the symptoms might be due to using the charcoal toothpaste for a long period of time causing abrasive action on the tongue to cause loss of filliform papilla and the color of charcoal itself for the black tongue.

Website: https://www.banglajol.info/index.php/UpDCJ 
Even in today's European population, nutritional deficiencies are a major medical issue. Dietary habits and socioeconomic status can play a role in the emergence of such issues ${ }^{5}$.

Megaloblastic anemia is characterized by abnormally large erythrocytes and is responsible for a variety of neuro disorders. It is caused mainly by a lack of vitamin B12. and/or a lack of vitamin B9. Megaloblast cells have irregular nuclear material due to a mismatch between nuclear maturation and cytoplasmic contents. Megaloblasts often have a problem with DNA synthesis and are stuck in the S-phase of the cell cycle ${ }^{6}$. In this study, the deficiency is due to a lack of nutritious food intake. Because of their relatively high cost, lack of availability, and/or cultural and religious beliefs, the diets of populations in low-income countries, especially those of the most vulnerable groups, are typically low in animal-source foods. Many such populations have become evident with a high prevalence of deficient and marginal B12 plasma vitamin ${ }^{4}$.

While the key causes remain the insufficient amount and low quality of the food, many other variables have been identified to cause malnutrition to persist in a population 7 . Papillary atrophy is one of the most common symptoms of vitamin B 12 deficiency. Vitamin B 12 deficiency results in shiny, glossy tongues with a red or pink background ${ }^{8}$.

It would have been better if biopsy of the tongue can be taken to confirm the diagnosis but the patient preferred the drugs and the symptoms subsided quite early after the administration of drug and intake of dietary foods.

\section{CONCLUSION}

Megaloblastic anemia is characterized by a complex pathogenesis. The dentist, who is often the first to be consulted, has a unique ability and obligation to assist in diagnosis. Follow-up is the secret to a satisfactory result in these patients. It's also important to think about the patient's eating patterns. In the absence of an underlying medical condition that prevents nutrient absorption, dietary advice should be provided. Alternative solutions for meeting dietary needs should be incorporated in these situations.

PATIENT CONSENT: Author proclaimed that the patient's has given consent regarding images to be share for research and journal publication.

\section{REFERENCES:}

1. Yadav MK, Manoli NM, Madhunapantula S V. Comparative Assessment of VitaminB12, Folic Acid and Homocysteine Levels in Relation to p53 Expression in Megaloblastic Anemia. 2016;40:1-17.

https://doi.org/10.1371/journal.pone.0164559

PMid:27780269 PMCid:PMC5079580

2. Antônio Rebelo Pontes $H$, Neto NC, Ferreira KB, Fonseca FP, Vallinoto GM, Sirotheau Corrêa Pontes F, et al. Oral manifestations of vitamin B12 deficiency: A case report. J Can Dent Assoc (Tor). 2009;75(7):533-7.

3. Wang $\mathrm{H}$, Li L, LI Q, Song Y, Th L, Wang H, et al. deficiency (Review ). 2018;

4. Allen LH. Causes of vitamin B 12 and folate deficiency. 2008;29(2):20-34 https://doi.org/10.1177/15648265080292S105 PMid:18709879

5. Radochová V, Slezák R, Radocha J. Oral Manifestations of Nutritional Deficiencies Single Centre Analysis. Acta Medica Cordoba [Internet]. 2020;63(3):95-100. https://doi.org/10.14712/18059694.2020.25, PMid:33002395

6. Briani C, Torre CD, Citton V, Manara R, Pompanin S, Binotto G, et al. Cobalamin deficiency: Clinical picture and radiological findings. Nutrients. 2013;5(11):4521-39. https://doi.org/10.3390/nu5114521

PMid:24248213 PMCid:PMC3847746
7. Khan MR, Ahmed F. Physical status, nutrient intake and dietary pattern of adolescent female factory workers in urban Bangladesh. Asia Pac J Clin Nutr. 2005;14(1):19-26.

8. Niimi N, Mori N. Papillary atrophy of the tongue. Clin Case Reports. 2018;6(11):2283-4 https://doi.org/10.1002/ccr3.1808

PMid:30455939 PMCid:PMC6230633

To submit your manuscript, Mail us to : updci@hotmail.com

To see our latest issue, click the following link https://www.banglajol.info/index.php/UpDCJ 